\title{
GIOVANNI PAPINI'S JUDAS ISCARIOT: A STUDY IN TENDENTIOUS FICTIONAL IMAGINATION
}

\section{Frederick Hale}

\begin{abstract}
Sommario
L'argomento di questo articolo è la costruzione di Giuda Iscariota nella biografia semi romanzata di Giovanni Papini, Storia di Cristo. Nonostante l'insistenza di Papini nel sostenere di essersi attenuto alla lettera al Nuovo Testamento in tutta la narrazione c'è molto contenuto di fantasia e a questo proposito il capitolo "Il mistero di Giuda" non fa eccezione. Vengono sottolineate le critiche di Gesù alla diseguaglianza sociale e l'ideale cristiano di povertà. Guida fa da contrasto a Gesù e i suoi discepoli, come uomo ossessionato dal denaro e motivato dal desiderio di guadagni materiali. II Giuda di Papini si colloca nella tradizione in continua evoluzione della raffigurazione letteraria dell'arcitraditore a partire da Dante nel XIV secolo fino a Mauriac nel XX.
\end{abstract}

Although his stature is minuscule outside Italy, Giovanni Papini (1881-1956) loomed large as a man of letters in his native land. In the words of Ernesto Livorni, he was among its "most prolific and influential intellectuals of the first half of the twentieth century". ${ }^{1} \mathrm{~A}$ philosopher, novelist, poet, editor, and essayist who rarely felt constrained by conventional borders separating the genres in which he wrote, this Florentine remained in the literary limelight for nearly fifty years. To be sure, Papini's reputation has been eclipsed, and in recent decades he has received considerably less scholarly attention than in

1. Ernesto Livorni, "Giovanni Papini", in Dictionary of Literary Biography, vol. 264, Italian Prose Writers, 1900-1945 (Detroit: The Gale Group, Inc., 2002:233). 
his own day. Nevertheless, his works form a vital component of Italian intellectual and literary history, revealing the mind of an erstwhile radical whose turn to the right did not entail an abandonment of social ethical concerns.

Among Papini's best-known books is his Storia di Cristo, a quasinovelised biography of Jesus Christ which was published in 1921 and, after enjoying immense popularity in Italy, was translated into English and other European languages within the next few years. ${ }^{2}$ For the most part, the subject is treated in harmony with fairly conservative Roman Catholic doctrine, although it clearly bears Papini's personal stylistic stamp and reflects his commitment to revolutionary - though no longer necessarily political - ideals. Furthermore, in its obvious concern for social justice, some theologically sophisticated readers may perceive reflections of Pope Leo XIII's renowned 1891 encyclical, Rerum Novarum. The text is richly embellished with both fictional elements and authorial commentary about the relevance of events in the life of Christ to those of people in the twentieth century.

Despite the popularity of Storia di Cristo, many dimensions of it have escaped extensive scholarly attention, and the book is widely regarded as little more than an expression of its author's captivity to the dictates of his newly found faith. The present article is intended as one modest step towards redressing that misconception. In it I shall focus on Papini's construction of Judas Iscariot, paying particular attention to how this dimension, notwithstanding critical assertions to the contrary, actually departs from the Gospel texts to which Papini sought to be faithful, and place his Judas into the historical context of literary representations of that character.

2. Giovanni Papini, Storia di Cristo (Firenze: Vallecchi Editore, 1921). All citations are taken from this first edition. 


\section{The Evolving Portrayal Judas in Imaginative Literature}

Papini created his Judas against an evolving and complex tradition of depicting Judas Iscariot in literature and visual art. In European manifestations, the fallen disciple was almost inevitably depicted negatively until the Enlightenment, when sporadic efforts were first undertaken to rehabilitate his image to varying degrees. ${ }^{3}$ In Italian literary history, of course, one of the most renowned representations of Judas occurs in Dante's La Divina Commedia. The portrayal of Judas being eternally chewed by the devil at the centre of the Inferno, the ninth circle thereof eponymously labelled la Giudecca, is horrific:

Da ogni bocca dirompea co' denti un peccatore, a guisa di maciulla, sì che tre ne facea così dolenti

A quel dinanzi il mordere era nulla verso 'l graffiar, ché tal volta la schiena rimanea delle pelle tutta brulla.

"Quell'anima lassù c' ha maggior pena" Disse 'l maestro, "é Giuda Scariotto, che 'l capo ha dentro e fuor le gamba mena."4

Medieval European artists typically portrayed Judas with exaggerated Semitic facial features and surrounded by demons. In other depictions of his alterity outside the familiar fold of the faithful, he was occasionally painted as a black man at a time when Christianity was regarded - at least by its adherents in Europe - as primarily the religion of that continent's inhabitants, not as a faith for all the

3. For a useful sampling of illustrative examples, see Kim Paffenroth, Judas: Images of the Lost Disciple (Louisville: Westminster John Knox Press, 1997).

4. La "Divina Commedia" di Dante Alighieri. Vol. I: Inferno (Firenze: G.C. Sansoni, 1950: 253). 
world's nations. To cite but one fairly representative example of conventional portrayals, the fifteenth-century Florentine Dominican monk Fra Angelico put a conspicuously dark halo above Judas in his San Marco fresco of the Last Supper as well as in another, portraying the betrayal in the Garden of Gethsemane. The other disciples in these pictures are adorned with golden haloes. ${ }^{5}$ The radically different status of Judas is thus too obvious to overlook. In short, Judas was for many centuries essentially a negative referent, an object lesson for Christians. As Kim Paffenroth has observed, the "negative, frightening, and scolding images" of him were not gratuitous and without purpose but were intended to be "deeply positive and redemptive" as verbal and nonverbal admonitions: "Although Judas is eternally trapped on the other side of the abyss, his story has been used to lead people fro the darkness of the cross to the hope and light of the resurrection."

With the Enlightenment came numerous literary attempts to go beyond dismissive caricatures and come to grips with Judas as a complex human being. In some instances this was essentially a matter of elevating him from the status of a demonic person to that of a fairly normal man - a greedy sinner, to be sure, but nevertheless human and thus not essentially different from either his fellow apostles or modern-day readers. The eminent German poet Friedrich Gottlieb Klopstock (1724-1803), for instance, in his epic poem Der Messias, completed in 1773, posited that Judas was envious of John, the beloved disciple, and his own frustrated ambition drove him to betrayal.

5. Paolo Morachiello, Fra Angelico. The San Marco Frescoes (London: Thames and Hudson, 1996:304).

6. Paffenroth, Judas: Images of the Lost Disciple:32. 
European intellectual attempts to rehabilitate Judas gained momentum during the nineteenth century. To cite one notorious example of an early step along this road, the noted French philosopher and Orientalist Ernest Renan (1823-1892) sought to reduce Judas' culpability in his controversial book of 1864, Vie de Jésus, a tome which was read internationally for several decades. To his credit, Renan, who had abandoned his studies for the priesthood by the mid1840s and turned his back on orthodox Roman Catholicism before the close of that decade, acknowledged that the "wretch" Judas had been "actuated by motives impossible to explain" and did not venture far out on the thin ice of speculation in this regard. Instead, he focussed primarily on deconstructing the New Testament portrayal of Judas and challenging theories of motivation which more recent writers had advanced. "Legend, which always uses strong and decisive language, describes the occupants of the little supper-room as eleven saints and one reprobate," Renan observed. "Reality does not proceed by such absolute categories." He dismissed the common attribution of the betrayal to "avarice" as implausible: "It would be very singular if a man who kept the purse, and who knew what he would lose by the death of his chief, were to abandon the profits of his occupation in exchange for a very small sum of money." Turning to another common theory, it seemed to Renan inadequate to explain the betrayal as a reaction to the rebuff he had received after criticising Mary for anointing Jesus. Finally, Renan disputed the Johannine indications (John 6:65 and 12:6) that Judas was "a thief, an unbeliever" from the outset, and stated without explaining why that "there is no probability" for this. $^{7}$

Instead, Renan cautiously suggested that the cause may have lain in "some feeling of jealousy or to some dissension amongst the disciples" and found evidence for this in "the peculiar hatred John

7. Ernest Renan, The Life of Jesus (London: Trübner \& Co., 1864:263-264). 
manifests towards Judas". In tandem therewith, Renan believed that differences regarding the management of the apostolic funds also underlay difficulties, not least by making Judas "narrow-minded". "By a caprice very common to men engaged in active duties, he had come to regard the interests of the treasury as superior even to those of the work for which it was intended," theorised Renan. "The treasurer had overcome the apostle." In addition to the disagreement concerning the anointing at Bethany, he suggested that the dire financial straits in which the disciples presumably found themselves created a difficult environment in which differences of opinion became magnified. ${ }^{8}$

Renan did not absolve Judas of all guilt in the plot against Jesus but argued that "the curses with which he is loaded are somewhat unjust." The betrayal, he thought, was characterised by "more awkwardness than perversity". Clearly assuming that Judas was sympathetic to and possibly involved in subversive activities against the Roman occupation, Renan reminded readers that the political atmosphere of the times was charged, indeed, one in which "a trifling spite sufficed to convert a partisan into a traitor." The outcome of the conspiracy for Judas also evoked Renan's sympathy. He thought the remorse and suicide of Judas proved that he had not "lost the moral sentiment completely". 9

Among the most prominent French littérateurs of the twentieth century who tackled the Judas theme in what might be called a relatively conservative literary treatment was François Mauriac (18851970) in his 1936 Vie de Jésus, a hybrid work which incorporates elements of both biography and fiction, as does Storia di Cristo. This pre-eminent Roman Catholic author and future Nobel laureate, who had been elected to the l'Academie française in 1933, did not venture

8. Renan, The Life of Jesus:264.

9. Renan, The Life of Jesus:264-265. 
far from a conventionally negative image when painting a fairly nuanced portrait of the betraying apostle. Mauriac's Judas is, for the most part, a normal but unambiguously self-serving man, one who desired material success and became associated with Jesus in the hope of appropriating some of his spiritual leader's power. Gradually Judas comprehends that the kingdom of Jesus is not of this world and, having accumulated some money which he has withheld from the common apostolic treasury, he seeks to extricate himself from the new messianic movement which he believes is doomed. $\mathrm{He}$ is thus revealed to be dishonest and conniving. On a more dastardly level, Mauriac's Judas is guilty of complicity with the Sanhedrin in plotting against Jesus, although very few details about this are given. While waiting for an opportunity to betray him, Judas pilfers from the common purse he administers for the other apostles. ${ }^{10}$ After accepting money from the priests in Jerusalem, he nevertheless vacillates about betraying Jesus until the last supper, when (echoing a theme from Klopstock's Der Messias which had reappeared in some other theological and fictional treatments of Judas) he becomes envious of the status enjoyed by the beloved disciple John and takes his crucial decision when Satan enters him. "Judas raged with jealousy, too astute not to understand that he was kept at a distance, that as John was the most loved, he had always been the least loved". ${ }^{11}$

Mauriac's construction of Judas' specific motive is at this stage faithful to the gospels and entails little authorial imagination. Jesus merely declares: "Amen, amen, I say to you, one of you will betray me". ${ }^{12}$ Yet Mauriac is sympathetic to Judas and excuses him from the demonisation to which his reputation had traditionally been subjected.

10. François Mauriac, Life of Jesus (London: Hodder and Stoughton, 1937:205.)

11. Mauriac, Life of Jesus:228.

12. Mauriac, Life of Jesus:226. 
The betrayer did not foresee the crucifixion. "There are no monsters; Judas had not believed that things would go very far - imprisonment perhaps several stripes from the scourge, and the carpenter would be sent back to his bench," Mauriac relates. Calling attention to the Biblical testimony that Judas repented, he speculates sympathetically: "He might have become a saint, the patron of all of us who constantly betray Christ. [. . .] Judas was on the border of perfect contrition. God might still have had the traitor needed for the Redemption [. . .] and a saint besides". ${ }^{13}$

\section{Papini’s Metamorphosis}

Storia di Cristo came at a critical juncture in Papini's life and intellectual career. Previously an intellectual radical and, like his father, an atheist, the young writer underwent a profound metamorphosis during the latter half of the second decade of the twentieth century. While the First World War raged in several parts of Europe, he began to investigate religious themes. This interest comes to the fore in such works as La paga del sabato (1915) and Polemiche religiose (1917). These are not from the pen of a hard-core believer, to be sure, but they foresaged what was to come. Weary of the chaos of industrial society and the intellectual strife in which he had been embroiled, Papini then retreated to a rural area between the Arno and Tiber rivers to recuperate and there discovered a mode of life which appealed to him. The rustic Tuscan peasantry struck him as possessing a certain native charity and decency, and, although their religious sophistication was extremely limited, for the most part they were still faithful to the life of the Roman Catholic Church, in which they worshipped, were baptised, were married, and were buried. When Papini began to read Biblical narratives aloud to some of them for

13. Mauriac, Life of Jesus:248-249. 
their edification, he discovered that he was just as profoundly influenced as they. ${ }^{14}$

He began to write Storia di Cristo in 1919 and approached his subject with the proverbial zeal of a convert. As he told his friend, the noted philosopher and historian Benedetto Croce, the Sermon on the Mount had impressed him profoundly, and in connection with his reading of the teachings of Christ he had come to the realisation that the only salvation for mankind lay in radical changes in individuals' souls. Yet for all its theological conservatism, Storia di Cristo betrays the revolutionary mind of its author. Papini's conversion experience was dramatic, but through it he did not completely sever his links with his previous convictions about the necessity of social transformation.

Perhaps nowhere is this more succinctly obvious than in Chapter XXX, "Il Capovolgitore". Papini cited numerous examples of intellectual, political, and religious figures who had challenged accepted truths and existing paradigms of thought. "Ma il più grande Rovesciatore è Gesù," he averred. "Il supremo Paradossista, il Capovolgitore, radicale e senza paura." To Papini, the revolutionary aspect of Jesus was the key to his evergreen magnitude; it was "la sua eterna Novità e Gioventù. Il segreto del gravitare d'ogni gran cuore, presto o tardi, verso il suo Evangelo" (121). To Papini, the life and teachings of Jesus evoked transformations in both the spiritual and the material realms. His interpretation of Judas can in large measure be read as disgust with how Judas countered, either volitionally or otherwise, the needed revolution in sinful mankind.

Papini's depiction of Judas is part of his strategy of creating a crucial binarism in characterisations of Judas and Jesus. They are foils to each other. This is partly with regard to their attitudes towards money;

14. “An Italian Life of Christ”, The Times Literary Supplement, no. 1, 17 (14 July 1921:446). 
Jesus is an honest labourer who never touched it, but Judas is a greedy money grabber.

Crucial to an understanding of the literary technique in Storia di Cristo, not least with regard to the character of Judas Iscariot, is an awareness that despite Papini's efforts to adhere closely to the letter of Scripture, he actually granted himself considerable freedom in creating the personalities of people in the gospels. This book is thus quite correctly described as at least partially fictional. Repeatedly Papini went beyond the text he was interpreting and drew on both traditions and his imagination. Nowhere is this more explicit than in the portrayal of Jesus. Undoubtedly relying on what for centuries had been a popular belief, Papini devoted the entire tenth of his 129 chapters to portraying Jesus as a carpenter. He attempted to do this in an artistic way, describing the perspiring hands of a labourer which for years drove nails into wood and would eventually become nailed to the wood of the cross. At the same time, however, Papini reminded readers that "Gesù non è stato alle scuole degli Scribi nè a quelle dei Greci" but in fact had three masters, namely the the "più grandi dei Dottori: il Lavoro, la Natura e il Libro" (28).

Moreover, he had been schooled through his intimacy with manual trades, having pursued "uno dei quattro più antichi e più sacri. Quelle del Contadino, del Muratore, del Fabbro, del Legnaiolo [. . .]" (28-29). His experience in carpentry provided metaphorical training for his ministry: "Il mestiere gl' insegnò che vivere significa trasformare le cose morte ed inutili in cose vive ed utili" (31) - an obvious foreshadowing of Jesus' bringing life to people who are spiritually dead in sin. This portrayal of him also allowed Papini to distance Jesus from the Jewish religious establishment and Hellenistic culture as far as his spiritual formation was concerned.

Moreover, and quite in harmony with Papini's criticism of modern economies, Jesus is financially pure. Somehow - notwithstanding his 
years of direct participation in the economy of Nazareth - "Gesù non ha mai voluto toccare, colle sue mani, una moneta" (289). The most obvious reason for these assertions is to distance Jesus from what Papini insists is filthy lucre: "Fra tutte le cose immonde che l'uomo ha manifatturato per insudiciare la terra e insudiciarsi, la moneta è forse la più immonda. [. . .] La moneta, che ha fatto morire, tanti corpi, fa morire ogni giorno migliaia di anime" (291-292). As we shall see shortly, this denigrating depiction of money is part of the strategy employed to create a negative image of Judas.

Not only Jesus, but all his disciples, moreover, were "quasi tutti poveri" (255) - and thus, according to the logic of Papini's position, less morally tainted than they otherwise would have been. This generalisation is similarly problematical and unbiblical; there is no compelling evidence that the Twelve were without means. On the contrary, one was a tax collector who collaborated with the Roman occupation, while others were employed in the thriving Galilean fishing enterprise which exported its salted catch to other provinces of the Roman Empire. But such nuances would fit neither Papini's simplified conception of the New Testament milieu nor his agenda in presenting the origins of Christianity in idealised terms which would challenge the status quo.

\section{Explaining the Betrayal?}

Papini finally goes to the heart of the matter in Chapter LXXXIX, one of the longest in the book, titled "Il Mistero di Giuda". The overarching theme here is the impossibility of knowing precisely what stimulated Judas to commit his crime against his master. Despite his profound respect for the gospels, Papini readily admits that the four evangelists simply did not record enough to discern the motivation. Consequently, "Sessanta generazioni di cristiani vi hanno fantasticato attorno ma l'uomo d'Ishkarioth, benchè abbia fatto sulla terra nuvoli di discepoli, rimane caparbiamente indecifrato" (412). 
Papini found no satisfactory explanation in the words of Luke 22:3 that "Satan [. . .] entró in lui". That, he believed, was "non sono che la defrinizione del suo delitto", not the cause of it. What bedevilled Papini was why Judas, who he believed had previously not been under the sway of Satan, had caved in. Noting that the modern-day value of the thirty pieces of silver would be approximately 100 lire, he reasoned that "non ci sembra che mille lire siano un prezzo sufficiente per indurre un uomo, che i suoi compagni ci descrivono avaro, a commettere la più ripugnante perfidia che la storia ricordi” (413).

Papini also sought to deal with the identification of Judas as one of the Zealots who sought to throw off the yoke of the Roman occupation of Israel. Was the betrayal somehow politically motivated? By the 1920s New Testament scholars and others had long speculated that Judas had become a disciple of Jesus in the mistaken belief that a revolutionary movement was afoot, that the expected Messiah would lead a worldly revolution against oppression of the Jews. According to this theory, which had numerous permutations, bitter disappointment had set in when it became evident that Jesus did not match their expectations. In one of these interpretations, Judas had reacted angrily by delivering Jesus to the Romans. To Papini, this seemed quite implausible and heterodox. "Ma questa fantasia, alla quale i testi, sia canonici che apocrifi, non danno nessun appiglio, non gioverebbe a scagionare il venditore di Cristo: avrebbe potuto disertare i Dodici e mettersi in cerca di compagni meglio adatti per lui, che allora, come s' è visto, non mancavano" (414).

Did Judas simply lose the faith he had had for approximately three years as a disciple? This, too, had been broached as a possible explanation for his drastic change of conduct. Papini's attitude towards this eventuality was less dismissive than his low regard for the explanation rooted in Judas' possible involvement with Zealotry. Papini could not overlook a possible change of heart and subsequent 
decline of faithfulness in one who had been committed to a religious movement, and Papini did not attempt to denigrate this as a factor. In nearly the same breath, he touched on the possibility that Judas was acting out of vengeance. After all, Papini reasoned, "Non si tradisce senza odiare" (416). Furthermore, he allowed, there were reasons why Judas should have negative feelings about Jesus, not least after being rebuked at Bethany, a matter to be discussed below. Yet it seemed problematical that such a motive would have prompted Judas to seek out Caiaphas, the high priest in Jerusalem, and inform him of Jesus' whereabouts in the hope that this information would eventuate in severe punishment. "Ma pensava davvero che la sua denunzia avrebbe portato Gesù alla morte?" Papini asked (416). Read in the full context of what was recorded about Judas' behaviour in the gospels, the answer to this seemed negative. It seemed more plausible to Papini that Judas may have thought that Jesus would merely be subjected to relatively mild corporal punishment and forbidden to preach. After comprehending the enormity of his action and its consequences, Judas had returned the thirty pieces of silver and committed suicide. Those reactions, to Papini, suggested that vengeance in a major sense could not be cited as the motivation for the betrayal. Whether vengeance of a minor sort fit the story he did not say.

In fact, despite Papini's insistence that Judas' motives for the betrayal must remains shrouded in mystery, he could not resist the temptation to pierce through the fog and implicitly attribute at least part of the motivation to monetary greed. After discussing how little the disciples in general had to do with money and that Jesus had sent them out without even a bag in which to receive offerings, Papini noted that one of the Twelve was a glaring exception to this condition, namely Judas as the man responsible for the apostolic purse. And, he reasoned, the story of this reprobate supports his anti-monetary case: "Giuda è la misteriosa vittima immolata alla maledizione della moneta" (291). 
To be sure, in places Papini granted himself the licence to go beyond the word of Scripture in describing and seeking to analyse the mentality of Judas. In Chapter LXXII, for instance, which relates the anointing of Jesus at Bethany, he linked Judas quite explicitly to pecuniary motives in a way which presages a possible motive for the ultimate betrayal. In his attempt to understand Judas' hostility to Mary's act of reverence, Papini, apparently basing his assumption on the statement in John 12:6 that Judas was a thief, asserts, "E a Giuda piace il Denaro. Gli piace di per sé, gli piace come possibilità di potenza" (338). Judas loved money. He loved it for itself and also as representing power." For this categorical assertion there is no unambiguous evidence, nor is there for Papini's following attempt to discredit Judas' stated reason for criticising the anointing ("Si poteva vendere questo unguento per trecento monete d'argento, e poi distribuirle ai poveri!" [John 12:5]) by speculating about how Judas envisaged the future: "Parla dei poveri, Giuda, ma non pensa ai poveri ai quali Gesù ha distribuito il pane nelle solitudini della campagna sibbene ai suoi propri compagni, troppo poveri ancora per conquistare Gerusalemme, per fondare l'impero messianico, dove Giuda spera d'essere uno dei padroni" (338-339). Much of this sprang from Papini's fertile imagination. Nowhere in the gospels does the meagre information about Judas reveal what his messianic expectations were or that he expected to be a ruler in a messianic realm. Yet in his effort to draw further conclusions about how the anointing of Jesus pointed Judas' negative emotions in the direction of the betrayal, Papini could not resist pouring even more fantasy into his narrative, now linking it obliquely with sexual attraction: "Ed è invidioso oltre che avaro; invidioso come tutti gli avari. Quell'unzione silenziosa che ricorda la consacrazione del Re, e del Messia, quegli onori che una donna bella ha reso al suo Capo, lo fanno soffrire; l'eterna gelosia dell' uomo contro l'uomo di fronte a una donna si confonde colla cupidità delusa" (339). 
The depiction of Judas at the Last Supper represents the zenith of Papini's imaginative licence and willingness to go beyond what is recorded in the gospels. Reiterating in microcosm the binary thrust of his argument, he portrayed Jesus Christ and Judas as "il Venduto e il Venditore, il Figlio d'Iddio e l'Aborto di Satana" (426). Papini speculated about the latter's thoughts and fears in that tense environment: "Ma se Gesù, che doveva sapere, l'avesse denunziato agli Undici? E se costoro, per salvare il Maestro, gli fossero saltati addosso per legarlo, forse per ammazzarlo? Cominciava a sentire che precipitar Cristo alla morte non sarebbe bastato per salvar se stesso dalla morte, tanto temuta eppure così vicina" (426). All of this is fictional discourse.

Less imaginative, but hardly less vituperative, is the depiction of Judas at the time of the betrayal in the Garden of Gethsemane. Papini described "la faccia livida di Guida" twitching in the glow of the lanterns as the soldiers rush in. By studied contrast, "Il volto di Cristo, macolato di sangue rappreso ma più luminoso dei lumi, si protende al bacio dell' Iscariota" (455-456).

\section{Conclusion}

Considered in its proper historical context of religious literature, much of the significance of Papini's construction of Judas lies in its relationship to the larger question of biographies of Jesus. After all, interest in Judas as a solitary figure would obviously be virtually nil. One must therefore ask whether Papini, despite his awareness of numerous European intellectual currents, was simply incognizant of recent developments in New Testament scholarship when he wrote Storia di Cristo. In 1906 Albert Schweizer of the University of Strasbourg had published his monumental Geschichte der Leben-JesuForschung (which was published in English four years later under the title The Quest of the Historical Jesus but never appeared in an Italian edition). In that watershed work, the future Nobel laureate argued 
cogently that the primary sources of information - the four canonical gospels - did not suffice for the construction of detailed biographies. "From these materials we can only get a Life of Jesus with yawning gaps," he stressed. "How are these gaps to be filled? At the worst with phrases, at the best with historical imagination." 15 Schweitzer demonstrated how since the eighteenth century writers, especially German theologians, who had nevertheless tried their hand at crafting biographies of Jesus of Nazareth had tended to create him in the image of their own ideological preconceptions.

Much the same can be said for reconstructions and interpretations of Judas Iscariot, about whom the sources reveal considerably less than the man whom he betrayed. To a great extent both antecedent and subsequent descriptions of Judas inescapably rest on the same infirm foundation. Papini's Judas is in this respect typical. Notwithstanding Papini's efforts to remain faithful to the narratives in the New Testament (and the naïve assurances of some commentators that he had succeeded in attaining that goal), his fictional Judas is not an objective image of the historical figure and, since so little can be known about him, could not have been expected to be so. The Judas of Storia di Cristo, like those of Klopstock, Renan, Mauriac, and other littérateurs is in large measure a product of its author's imagination and purposefully shaped to serve Papini's strategic representation of Jesus.

(University of Stellenbosch)

15. Albert Schweitzer, The Quest of the Historical Jesus (London: Adam and Charles Black, 1910:7). 